\title{
EFFECT ON THE FINANCIAL CONDITION AND PROFITABILITY OF NON- FINANCIAL PERFOMANCE IN THE INDONESIAN SHIPPING COMPANY
}

\author{
Supardi
}

\author{
Higher Education of Economic Mandala \\ e-mail: Supardi@stie-mandala.ac.id
}

\begin{abstract}
Abstract: One problem often encountered by management in the shipping industry companies in Indonesia are financial problems, because it collided with the availability of working capital which the company cannot be operated because the funds will be used for the purchase of raw materials and to give employees salary.This research analyzes the influence of financial condition consisting of working capital, asset structure, operating leverage, and sales growth on the firm profitability as well as on its non financial performance of ship building companies in Indonesia. By employing the multiple regression, the result of the estimation showed that among those variables underlined, working capital, asset structure, and sales growth proved to be significantly affecting the firm profitability and its nonfinancial performance, meanwhile the operating leverage has been proved non-significant. This research concludes that the management should pay more attention on working capital and the asset structure being the predominant variable, besides its asset structure and the sales growth, affecting the ship building companies performance in Indonesia. Shipping companies can grow and expand. To be able to increase profitability by increasing the shipping company's own capital and reducing a portion of the shipping company, the more active equity and profitability will also be good. On the other hand if it continues to rely on capital from outside, it will cause emergence of interest expense to be borne by the shipping company.
\end{abstract}

Keyword: Working Capital, Asset Structure, Operating Leverage, Sales Growth, Profitability, Non-Financial Performance.

\section{INTRODUCTION}

Indonesia, as a maritime state, can show their dominance in their own waters appropriately. However, the facts show that $95 \%$ of domestic shipping lines are still dominated by foreign shipping. Improved infrastructure adequate shipbuilding industry and high-tech is beginning to catch up phase of the Indonesian people in the field of technology of repair and ship building. In connection with this, it is necessary to mapping conditions existing shipbuilding industry, to determine the extent of progress made by the shipbuilding industry today. The tendency of the company's position in this mapping can be used as input for the Management in conducting the remedial efforts in the future. This stage uses four main aspects, namely the financial aspect, customer, internal business, and learning and growth. A company at this time will not be able to compete if only relying on the economic side alone without regard to other aspects are interrelated.

This research focus on the development condition and competitiveness of national shipyards, particularly in the era of competitive global market competition. Therefore, this 
dissertation shows background of the research, include: practical background (shipbuilding business and its problems) and academic background, the formulation of research problems, hypotheses, scope, objectives and benefits of research results. National Industrial Development Policy Direction refers to the agenda and priorities of the National Development. United Indonesia Cabinet within the framework of the National Medium Term Development Plan (RPJMN) 2010-2014 (Presidential Decree No. 5 of 2010), namely: (1) Delivering Welfare, (2) Achieve Democratic, and (3) Achieve Justice. For Indonesia's industrial development strategy in the future will adapt to the latest ideas developed at this time. The era of globalization and the development of 21 st century technology provide an approach to the development of industrial sector in the context of building a comprehensive industrial competitiveness and sustainable.

Based on the development of the shipping industry in general, it is known that the problem of investment is also an important issue, other than issues of marketing, human resources, production and others. It is the responsibility of the financial manager in making decisions. The issue of this investment is very important for shipping companies as a matter of the source of funds for investment, and the economic life of the most important is the expected return and investment. Every company certainly does not want money or capital owned wasted without getting the results as expected, so the decision regarding the investment affects the firm's performance. Less proper decision making in the investment will result on lowering performance of the company.

One problem often encountered by management in the shipping industry companies in Indonesia are financial problems, because it collided with the availability of working capital which the company can not be operated because the funds will be used for the purchase of raw materials and to give employees salary. Finance function is very important, because it involves all activities related to the business of the company to obtain funds and use these funds effectively and efficiently. For each course, the effectiveness of which made the need for the expenses of the sources of capital, either in the form of working capital and investment capital.

Assessment of performance by utilizing financial information as a single indicator has been used extensively, but only by reviewing financial measures as a single indicator is not showing excellent results to assess the performance of a company (Kaplan et al, 2000). therefore, evolved on the basis of performance appraisal system that more comprehensive, which is not only used to measure the performance of the financial aspects of the company but also the use of non-financial aspects as part of an information system. Any talk of the public service will touch on the quality of services provided by public organizations in the community as customers. Quality of service is generally focused on the customer, so that the products services designed, manufactured and supplied to meet customer desires and satisfaction in this study is the shipping industry customers. So in this study in terms of non-financial performance assessment through customer satisfaction.

Inadequate working capital will make the company can not run optimally on corporate activity and if excessive working capital available, this has resulted in the use of working capital is not productive. This means that any company should be able to optimally utilize the working capital as needed in carrying out its activities. Given the importance of working capital in a shipping company in Indonesia is the reason for the author to examine the influence of the dimensions of the financial condition and profitability of non-financial performance in the Indonesian shipping company. 
This research aims to examine the effect of the dimensions of financial condition consisting of Working Capital, Asset Structure, Operating Leverage and Sales Growth to profitability in the Indonesian shipping company and to test the effect of the dimensions of financial condition consisting of Working Capital, Asset Structure, Operating Leverage and Sales Growth of non-financial performance in the Indonesian shipping company.

\section{Profitability}

Profitability by Riyanto (2001) is the company's ability to generate profits for a certain period. Weston and Copeland (1999) argues that the profitability is the net result of a series of policies and decisions. While Baridwan (2005) defines the profitability is the ability of the company makes a profit in relation to sales, total assets and own capital. Each company is always trying to improve profitability. If the shipping company managed to increase its profitability, it can be said that the shipping company is able to manage its resources effectively and efficiently so as to produce high profits. Conversely, a shipping company has low profitability shows that the shipping company is not able to manage its resources well, so it is not able to generate high profits.

One of the profitability ratios is often used in research related to the effects return on investment is the return on investment (ROI). Return on Investment (ROI) demonstrate the company's ability to generate profits from assets that are used. Knowing this ratio, it can be seen whether the company will be efficient in utilizing its assets in the company's operations. The results of previous studies, that ratio also provides a better measure for the profitability of the company as it demonstrates management effectiveness in using assets to generate revenue (Baridwan, 2005).

\section{Financial Performance}

The first thing to do is determining the health of the financial management of the company, the next is to look at the financial performance of the company's financial statements. Sucipto (2003: 34) defines financial performance is the determination of certain sizes that can measure the success of a company in generating profits. Financial performance said by Fahmi (2011: 2), is an analysis done to see how far a company has performed by using the rules of financial performance which is good and right. The stages applied for analyzing the company's financial performance. There are five (5) steps in analyzing the financial performance of a company in general, namely: a) Conducting a review of financial reports, b) Performing calculations, c) Doing a comparison of the results of the count being obtained, d) Doing interpretation of the various problems that are found, and e) Finding and providing solutions to the problems found. It can be concluded that the financial performance is an analysis has been conducted to determine the extent of the company carrying out the rules in the management of the company is good and right.

\section{Non-Financial Performance}

According to the theory of Kaplan and Norton (1995), non-financial performance is measured by customer market share benchmark, how much the market segment occupied, the rate of new customer acquisition, the ability to retain existing customers, customer satisfaction, customer profitability and the level of corporate image in eyes of the customer and performance-related internal processes consisting of innovation, operation and after-sales service. Then the non-financial performance of the learning and growth consists of employee capabilities, information system capabilities and motivation. Non-financial performance is a feat achieved by the shipping company within a certain period which reflects the 
soundness of the shipping company. Indonesian shipping company as a form of organization in general has specific goals to be achieved in an effort to meet the interests of its members.

\section{Financial Condition}

For parties which interested in the development of an Indonesian shipping company are very necessary to know the financial condition of the company. The financial condition of an Indonesian shipping company can be ascertained from the financial statements consisting of balance sheet, income statement, statement of changes in equity, cash flow statement, and notes to the financial statements.

\section{Working Capital}

Working Capital is the net capital represents the excess of current assets to current liabilities, to fund operations. According to the theory of Weston and Copeland (1999), working capital is the difference between current assets by current liabilities. Thus, working capital is an investment in cash, marketable securities, accounts receivable and inventories minus current liabilities are used to protect the current assets. An analysis of the sources and uses of working capital is very important for the analysis of internal and external, in addition to the problem of working capital is closely related to the daily operation of the company also have a lower margin of safety or the security of the creditors, especially short-term creditors. Indonesian shipping company operating costs depends on working capital from banks or investors. The disadvantage of working capital is its deficiency results in decreased earnings capacity as a result of the slow turn over of the company. This gives rise to the impression that the management is not able to use working capital efficiently. If the working capital gets loan from the bank, the company suffered a loss in pay interest. While the good thing of working capital is to protect the possibility of a financial crisis in order to fix the necessary working capital, planning and overseeing the company's plan to become a financial plan in the short term, and to assess the speed of rotation of working capital in a holistic sense.

\section{Structure of Assets (tangibility)}

Baridwan (2005: 176) states: "The structure of assets is reflected in the left side of a balance sheet that shows the composition to be financed". According to Shamsuddin (2000: 8): "The structure of assets is the determination of how much of each component of the allocation of assets, both in current assets and fixed assets". Titman and Wessels (1988) suggest that the asset structure is: "Balance or the ratio between fixed assets to total assets". Companies with asset structure suitable as collateral debt tend to use greater leverage (Brigham and Gapenski, 1996: 511). For example: real estate companies tend to have greater leverage than a company engaged in the field of technology. Companies that have assets that can be submitted as collateral, tend to use large amounts of debt (Weston and Brigham, 1997: 713). Assets are assets that is associated with the company's capital structure is primarily fixed assets. If the composition of a company is capital intensive, meaning the company prioritizes its own expenditure. That is, only the loan capital is complementary particularly for working capital financing (Napa and Mulyadi, 1996: 60).

\section{Operating Leverage}

Leverage is the use of assets or funds that have fixed costs to magnify returns (return) to the owner of the company (Gitman, 2006). Leverage in conjunction with the income statement, is operating leverage and financial leverage. Operating leverage is required when a company has fixed operating expense in the cost structure. With the fixed operating expense percentage increase in the percentage of sales will cause a greater 
increase in EBIT. Measurement of operating leverage is to use the degree of operating leverage (DOL). Financial leverage is required when a company has financial fixed expense in the cost structure. With the financial fixed expense, the percentage increase in operating income percentage increase will lead to a greater net income. Measurement of financial leverage is to use the degree of financial leverage (DFL). Agency theory predicts that firms with higher leverage ratios will reveal much more information, because the cost of agency companies with capital structure as it is higher (Jensen and Meckling, 1976: 354). Operating leverage shows how large companies use the load remains operational. Expenses remain operational are usually derived from the depreciation costs, production costs, and marketing permanent. Companies that use a fixed fee in a high proportion (relative to variable costs) is said to use a high operating leverage, in other words the degree of operating leverage (DOL) for the company is high. If a company has a high DOL, high level of sales will generate higher revenue. But conversely, if the level of sales dropped significantly the company will incur a loss.

\section{Sales Growth (Growth of Sales)}

The increase in the number of sales occurs from year to year or from time to time. The way the measurement is to compare sales in year $t$ minus sales in the previous period to the sales in the previous period are expressed in percent $(\%)$. The growth of shipping company in Indonesia indicates the company's ability to maintain its survival. In this study, the growth of the company is proxied by the ratio of sales growth. Companies with good growth will be able to increase its sales volume as compared to previous years. This shows the company's ability to maintain its economic position so as to provide an opportunity for the company to increase profits and maintain the viability of their business. Thus, the higher the sales growth ratio the less likely the company received a going concern audit opinion. According to the theory, that the growth in sales have strategic impact for a company, for sales made must be supported by such property or assets and increased sales when the asset must be added (Weston and Brigham, 1991: 95). Companies can optimize existing resources, by knowing the sales from the previous year.

\section{Hypothesis}

$\mathrm{H}_{1}$ : Working Capital significant effect on profitability in the Indonesia shipping company

$\mathrm{H}_{2}$ : Structure asset significant effect on profitability in the Indonesia shipping company

$\mathrm{H}_{3}$ : Operating Leverage significant effect on profitability in the Indonesia shipping company

$\mathrm{H}_{4}$ : Sales growth significant effect on profitability in the Indonesia shipping company

$\mathrm{H}_{5}$ : Working Capital significant effect on non financial performance in the Indonesia shipping company

$\mathrm{H}_{6}$ : Structure asset significant effect on non financial performance in the Indonesia shipping company

$\mathrm{H}_{7}$ : Operating Leverage significant effect on non financial performance in the Indonesia shipping company

$\mathrm{H}_{8}$ : Sales growth significant effect on non financial performance in the Indonesia shipping company

\section{RESEARCH METHODS}

\section{Research Design Used}

Design research is an associative design, which is to analyze the relationship between one variable with another variable or how a variable affects another variable. In this case the associative design used is a causal associative design is a causal relationship between one variable and the other variables. The authors used a case study with quantitative approach while the unit of analysis in this study was the effect 
of the dimension of financial condition (Working Capital, Asset Structure, Operating leverage, sales growth) to profitability and non-financial performance on Indonesian shipping company.

\section{Population and Sample}

The population in this study involved all Indonesian shipping company by 15 companies. The sampling method used is the census, which is full sampling as many as 15 companies with a 5-year study period from 2007 to 2011.

\section{Data Analysis Techniques}

To answer the research objectives, namely the influence of the dimensions of financial condition (Working Capital,

Asset Structure, Operating leverage, Sales growth) and profitability of non-financial performance in the Indonesian shipping company, it is used quantitative analysis techniques, namely: Testing the hypothesis in this study was performed using multiple linear regression models. After covering the Classical Assumption Test, it is followed by normalitas test, multicollinearity test, heteroscedasticity test and autocorrelation test.

\section{RESULTS ANALYSIS}

Based on empirical findings through quantitative methods, the recommended model is as shown in figure 1.

Figure 1

Model of the Effect of Financial Condition profitability and Non-Financial Performance

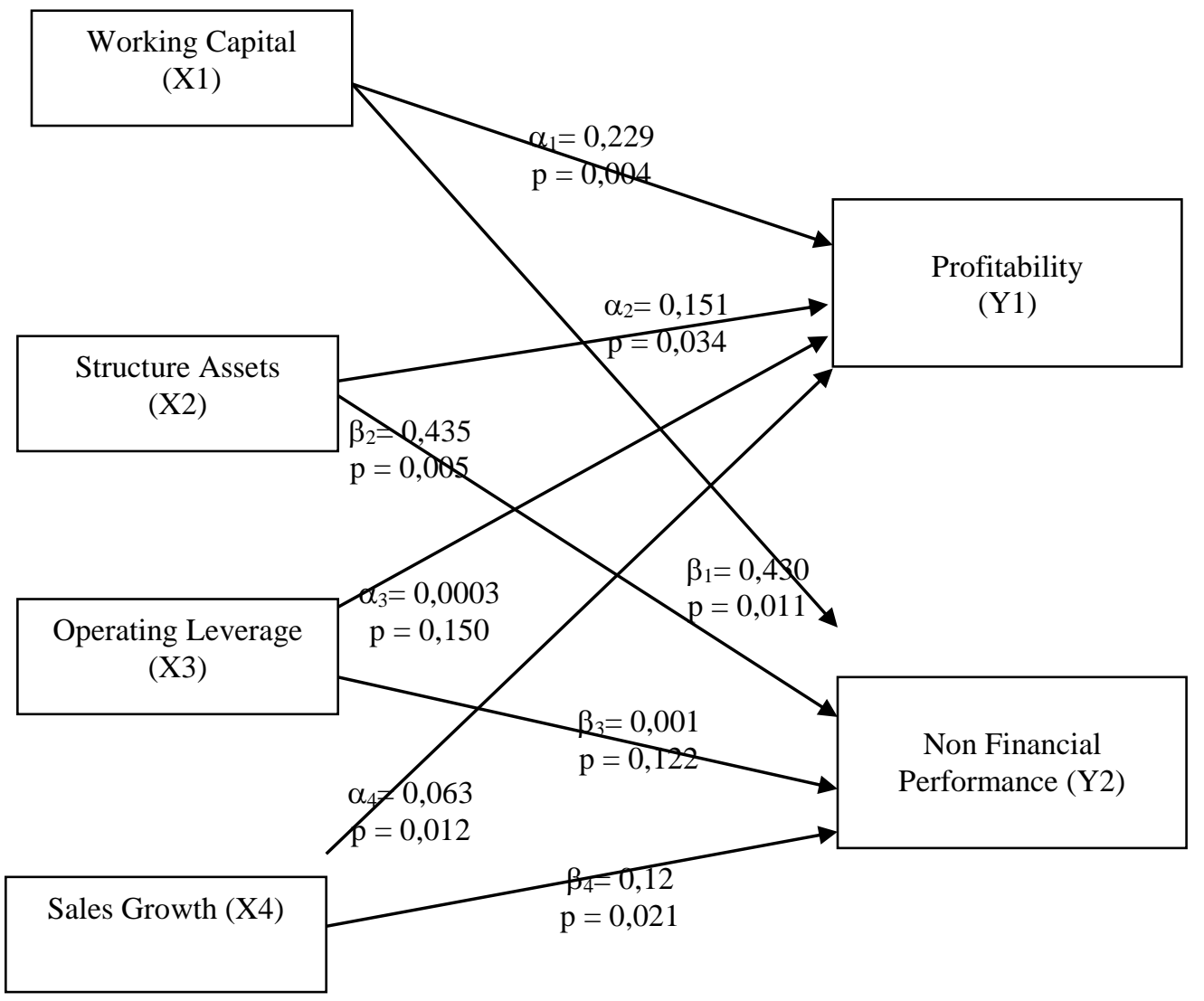

Source: Secondary data is processed.

The results of the empirical findings indicate that working capital, asset structure and growth affect sales and profitability of non-financial performance.

\section{INTERPRETATION}




\section{Effect of Working Capital to profitability}

Working capital has significant effect on profitability. This suggests that the management of working capital has a very important role to generate profit and to ensure the continuity of the company. Reduced working capital will be able to reduce the opportunities open to the company to improve profitability. The results of this study are consistent with research Nurak (2001), Raheman and Natsir (2007) and Nugroho (2011) which states that the working capital has a significant effect on profitability. The higher the amount of working capital to finance its use is governed expenses for the activities of the daily operation of the company will be profitable for the company because in addition to allowing the company to operate economically and the company is not experiencing financial difficulties. High working capital showed an excess of current assets or the existence of idle funds are funds that are useful to improve operations and profit, whereas a low working capital showed a lack of working capital due to capital and inventory turnover is slow. Each company is always in need of working capital to fund its operations both within the company that is engaged in the production of new vessels and repair. Working capital should always be spinning for companies conducting business. Companies have greater working capital, then the greater the company's ability to meet its short term obligations. This shows the company made a huge placement of funds in the current assets. Placement that is too big on the assets side has two very different effects.

If the company decided to establish working capital in large numbers, the possibility of liquidity will be maintained but the opportunity to earn large profits will decrease, which in turn decrease the profitability. The higher liquidity, then the company's position in the eyes of all right lender, therefore there is a greater likelihood that the company will be able to pay their obligations on time. On the other hand in terms of angle of shareholders, high liquidity is not always advantageous as potentially leading idle funds that could otherwise be used to invest in projects that benefit the company (Single, 1995).

Working capital of the company is a vital role for the sustainability performance of the company, because working capital is an amount that must be constantly there to support business activities. In addition, working capital as well as determine the continuity of the company's liquidity position. The need for working capital for each company is different, because of different forms and types of business carried on. Determination of the amount of working capital should be considered carefully, so that in practice it does not hamper the business activities and the company will also need to think about how to manage working capital effectively and efficiently.

Good working capital management is the responsibility of every leader of the company, so that in every use of the working capital the company can achieve a point of equilibrium in terms of supply and use of working capital. Working capital is less than the requirement will result in losses or missed opportunities for profit (profit). Instead of working capital that the amount is too large than required will result in idle funds, resulting in inefficient use of funds.

The availability of effective working capital, which means the amount of working capital, is available to meet the need for the activities undertaken by the company. However, the availability of working capital also should not be excessive, which means there are no idle funds allowing the company can operate well and have no problems if one day there is a financial hardship. According to Halsey (2005: 63), the total investment in the company consisting of the fixed assets and working capital (current assets) and corporate profits will increase seen from the relationship between income and 
expenses resulting from the use of company assets both fixed assets and working capital (current assets ) in productive activities. Return on capital investment is an important indicator for the strength of the company in the long run. Thus, by effectively managing working capital will increase the profitability of the company. Working capital and assets of the company was instrumental in the company's performance, so it takes careful thought in decision making related to investments in working capital.

\section{Effect of Asset Structure of profitability}

Asset structure significantly influence on profitability. This shows that the fixed asset is a capital of a company which can be used in the operation of the company for the operations of the company will generate revenue. Revenue represents the increase or decrease in the company's asset liability company (or a combination of both) during the specified period from the delivery of goods, delivery of services, or other activities that are central activities of the company. If income exceeds expenses, the company makes a profit. Generate the maximum profit is one of the goals of the company, because the greater the profit generated a company shows the company's health condition. One of the efforts of a company to maximize profit companies is through the management of existing fixed assets. Managers are required to manage assets properly through the process of production, distribution and others. The better asset turnover, it shows the company's health condition.

\section{Effect of Operating Leverage on profitability}

Operating leverage has no effect on profitability. Insignificant due to the company's operating leverage studied homogeneous i.e. shipping company. The more homogeneous the company in an industry, the fixed costs incurred by the company will be more uniform or relatively the same amount, so that fluctuations in corporate profits is only affected by fluctuations in sales are closely related to fluctuations in variable costs. The results of this study support the research Putra (2013) which states that the operating leverage no significant effect on earnings per share. The use of assets with fixed costs in the hope that the revenue generated by the user's assets will be sufficient to cover fixed costs and variable costs. Operating leverage shows how large companies use the load remains operational. Expenses remain operational are usually derived from the depreciation costs, production costs, and marketing permanent. Companies that use a fixed fee in a high proportion (relative to variable costs) is said to use a high operating leverage, in other words the degree of operating leverage for the company is high. If a company has a degree of high operating leverage, high level of sales will generate higher revenue. But it will turn conversely if the rate of sales fell to experience losses. The results of this study are inconsistent with research Wenty and Murtanto (2001), which is also inconsistent with research Raheman and Natsir (2007).

In every company is always in need of funds to meet all the necessary requirements in its activities, as well as the service companies that have high fixed costs, so companies need a lot of investment to cover the costs. Companies with Operating Leverage smaller tend to be able to increase financial leverage because the company will have a smaller business risk. By knowing Operating Leverage, management can assess changes in operating income as a result of changes in sales. Therefore, the operating leverage associated with the company's sales and earnings before interest and taxes.

Companies that use costs higher certainly require substantial profits, so companies are trying to get the maximum profit. One way to earn high profits is by 
using profitability, because it will measure the level of corporate profits. Analysis of enterprise profitability is a major part of financial statement analysis. All financial reports can be used for the analysis of financial statements, but the most important to review the profitability i.e. income statement. The income statement can report the results of operations during the period. In measuring profitability, one of which can be done by using the Return on Investment (ROI). Where it can measure the ROI of the company's ability to generate profits occur by using net profit after tax. Company's ability to earn income or profit of the operation will be a measure of the effectiveness of the company's management.

\section{Effect of Sales Growth of profitability}

Sales growth has significantly influence profitability. This suggests that the strong sales growth tends to increase its profit. The faster rate of growth of sales of a company the greater the funds needed to finance the company's growth. Therefore, sales growth is highly desirable because each company's sales growth reflects the growth of the company. The results of this study are consistent with research Deitiana (2011) which states that the sales growth has significantly influence profitability. Profits often be one measure of company performance. Companies that have high earnings mean the performance is good and vice versa. Profit is an indicator of a company other than the company's ability to meet obligations to donors is also an element in the creation of corporate value that indicates the company's prospects in the future. Sales growth has an important role in the management of working capital, to know how big the sales growth, the company can predict how much profit to be gained.

Shipping company will not run without a good sales system. Sales is the spearhead of a company. Appropriate sales forecast is necessary, so that the company can prepare everything necessary for the production process. By using the ratio of sales growth, the company can know the trend of sales of products from year to year. Brigham and Houston (2006) states that the sale should cover the costs so as to increase profits, then the company can determine the steps to be taken to anticipate the possibility of increase or decrease in sales in the coming year. If sales increased, the asset must be added, while on the other hand, if the company knows for certain future sales demand, the result of claims, as well as the schedule of the product, the company will be able to set up a schedule of debt maturities to match the net cash flows in the future to come. As a result, profits will be maximized (Horne and Wachowicz, 2009).

\section{Effect of Working Capital and Non- Financial Performance}

Working capital has significant effect on non-financial performance. This suggests that working capital is one of the most important aspects, of the overall management of the company spending. Therefore, companies must be able to maintain certain capital levels, if not maybe the company will be in a state illikuid (not being able to pay obligations already due) even the possibility had to be liquidated.

Working capital should be available within the company should be sufficient in number in the sense to be able to pay for expenses or day-to-day operations. Sufficient working capital will provide benefits to the company include:

a. Protect your company against the crisis of working capital due to the falling value of the current assets.

b. Allows the company to pay all obligations on time.

c. Ensure the credit standing of the company has become larger and allows for companies to be able to face financial difficulties that may occur.

d. Enables companies to have supplies in sufficient quantity to serve the consumer. 
e. Enables the company to provide more favorable credit terms to customers.

f. More efficient because there is no difficulty to obtain goods or services required.

Good management of working capital, expected capital tied up in the form of working capital can be used efficiently and effectively as possible, through the activities undertaken by the company. Financial management plays an important role in the planning and allocation of capital, because the success or failure of the company depends on the objectives of capital management are available. In planning the allocation of capital, financial management is required to make efficiency. All of them can be realized by drawing a policy decision in determining the required capital.

Working capital is an important element in running the business activities of the company, one of the conditions of success of a company is the proper management of working capital. Most causes of bankruptcy arises because of weak policies and decisions in the field of working capital, working capital management determines the company's liquidity position and liquidity requirements with the company's success is good management of working capital is expected to trigger labor to produce a quality product, a quality product is certainly desirable and sought after by the consumer / customer. When consumers / customers have confidence in the quality of the company's products, it is expected to increase the sales volume of these products so that eventually can affect the profitability of the company, which is one of the primary destinations in order to survive and compete with other companies.

\section{Effect of Structure on the Performance of Non-Financial Assets}

There is significant effect on the structure of assets of non-financial performance. This means that the asset structure play an important role in determining the optimal non-financial performance. Shipping companies to maintain and increase market share in targeted customer segments are beginning with retaining existing customers in that segment. Customer retention is very helpful to identify more character and value expected by the customer as a consideration of the strategies applied. Thus, to be able to support the needs of the company, in order to achieve success in the future with a strategy that is able to compete, we need a balanced view. Shipping company in growing the business on a national and international level need to set an objective to increase the customer base or target segment called customer retention.

\section{Effect of Operating Leverage of Non- Financial Performance}

The effect of operating leverage on non-financial performance is not significant. This means that the level of operating leverage does not affect the level of non-financial performance. Operating leverage is the use of the assets that give rise to operational fixed costs such as depreciation and others in the hope of obtaining income to cover fixed costs and variable costs. Shipping company is a corporate job order, in this case the use of the average fund companies use internal sources of funds, meaning that the source of funds coming from the company itself. The source arises from the existence of the results obtained from the course of business conducted by the company. From that effort, the company will get the results as well as earnings or profits. Operating leverage is the use of a particular property or assets which will increase the burden remains for companies such as machinery, buildings and so on, in this case will be a permanent burden of depreciation costs. Assets such as machinery and land on the shipping company before accepting the project so that the cost of depreciation have not been able to take into account the 
high point value. Operating costs incurred in order to keep sales volume can produce greater revenues than the entire fixed and variable operating costs. The influence arises in the presence of fixed operating costs, namely the change in the volume of sales that result in changes in the operating profit or loss that is greater than a predetermined proportion.

\section{Effect of Sales Growth of Non-Financial Performance}

There is significant effect on the growth of sales of non-financial performance. Sales growth reflects the successful manifestation of the investment period of the past and can be used as a prediction of future growth. Sales growth is also an indicator of the demand and the competitiveness of firms in an industry. The rate of growth of a shipping company will affect the ability to sustain gains in funding opportunities in the future. High level of sales to customers is the result of customer loyalty. With customer retention analysis concluded that customer loyalty can be formed by increasing the quality and attention to timely delivery. So the improvement in terms of timely delivery will increase customer loyalty that ultimately will improve financial performance. Customer loyalty and timely delivery will be included in a customer's perspective. Further to be seen whether the internal business processes that need to be done as best as possible by the company if they want to obtain timely delivery. How to maintain and increase market share in the targeted customer segment is preceded by retaining existing customers in that segment (customer retention). In addition to retaining customers and more companies want to be able to measure customer loyalty through business percentage growth with existing customers, in general, the company wants to increase business by setting goals to increase customer base in all targets, measure customer retention measure in the form of absolute and relative strength of the business unit attract and win new customers. Customer retention can be measured by the number of new customers or the number of sales to new customers in existing market segments (Kaplan and Norton, 2000: 61).

Sales growth indicates a company's ability to survive in the competitive conditions of the company. Sales growth is higher than the increase in costs will result in increased profits. The amount of profit earned on a regular basis as well as a tendency or trend of increasing profits is a crucial factor for the company stay afloat. In general, companies that grow quickly obtain positive results in terms of strengthening the position in the competition, enjoying sales increased significantly and was accompanied by an increase in market share. Fast-growing company has also benefited from the positive image is obtained, but the company will have to be extra careful, because the success is obtained by causing the company becomes vulnerable to any negative issues. Shipping companies need to get an important concern of the government, especially on working capital because it can reduce the negative news sources that describe the company's ability to maintain, develop and degrade the quality and lower customer satisfaction. Shipping company is a company that requires huge capital. In order to increase sales productivity, it should be noted the readiness of human resources. Increased growth of the company shall have the meanings if cost control less attention.

\section{CONCLUSIONS}

Based on the analysis it can be concluded that more competition against shipping companies, then the profit cannot exceed $10 \%$ of the selling price so that shipping companies tend to lose. Moreover, working capital funded by bank loans or borrowing from investors is very volatile so that the shipping company is difficult to increase profits. Evident from the research, that the financial condition as measured by the effect on profitability and 
working capital Indonesian shipping company. The need for working capital is one element that is very important asset in the company, because without the working capital the company is not able to meet the needs funds to run its activities. A financial manager is required to pay attention to the source of funds to meet the working capital so that managers faced with a wide choice of sources of funds, both short-term sources of funds as well as long-term. The source of these funds is used as a source of financing and the management of the company in every activity of the company to be more efficient and ready to face competition in the company future. This suggests that the management of working capital has a very important role in generating income and ensure the continuity of the company, reduced or excess working capital will be able to reduce the opportunities open to the company Indonesian shipping company to increase profitability. The results of this study are consistent with research Nurak (2001), Raheman and Natsir (2007) and Nugroho (2011).

The company is a shipping company based on job order so that the value of the asset structure varied according to the value of the contract and the type of vessel that is ordered from the buyer. It can be concluded assets structure significantly influence profitability. Determining the structure of a good asset for the shipping company is no easy task. Managers need to be careful and use appropriate calculation to determine how much investment in fixed assets and the amount of current assets that are both balanced right. Riyanto (2008) explains that the structure of assets is the ratio between current assets, fixed assets, and required careful consideration in terms of determining the proportion of the two types of assets. Companies that have total assets of the generally greater use of longterm capital, while companies that more use would be to use your current assets are generally short-term capital. The longer the period of use of an asset in the company, the greater the risk given the development and advancement of technology and science are endless, economical in terms of an asset may have a relatively short lifespan, although technically still usable. That is, the investment decision should be taken into account in the economic life of the assets, costs, and risks that may arise. This shows the importance of determining the structure of assets in the shipping company. In determining how the exact composition of the asset structure required a manager's ability to analyze situations in the past, as well as estimates of future long-term goals associated with the shipping company. This shows that the fixed asset is a capital of a shipping company that can be used in the operation of the company as in the operational activities, the company will generate revenue.

Leverage is the use of assets or funds that have fixed costs to magnify returns (return) to the owner of the company (Gitman, 2006). The company is a shipping company based on the order that the use of assets fluctuate in accordance with the company obtained orders. Operating leverage of research revealed no effect on profitability. The results of this study support the research of Putra (2013) which states that operating leverage has no effect on earnings per share. However, it is inconsistent with the research of Wenty and Murtanto (2001) and Raheman and Natsir (2007).

The growth of shipping company in Indonesia indicates the company's ability to maintain its survival. Theoretically, that sales growth has a strategic impact for a company, for sales made must be supported by such property or assets and increased sales when the asset must be added (Weston and Brigham, 1991: 95), so the conclusion of the study is that growth significant effect on the profitability of sales. This suggests that the strong sales growth tends to increase its profit. The 
results of this study are consistent with research Deitiana (2011).

Indonesian shipping company operating costs depends on working capital from banks or investors. The disadvantage of working capital is working capital deficiency results in decreased earnings capacity as a result of the slow turnover of the company, with less working capital to support the resulting performance of the company also declined. It can be concluded that the working capital significantly influence the performance of non-financial Indonesian shipping company. This suggests that working capital is one of the most important aspects, of the overall management of the Indonesian shipping company spending. The company is a shipping company based on job order so that the value of the asset structure is varied according to the value of the contract and the type of vessel that is ordered from the buyer. It can be concluded that the company's assets do not accumulate to use because waiting for a similar project. Studies showed that the structure of assets have a significant effect on the performance of non-financial Indonesian shipping company. This means that the asset structure play an important role in determining the optimal nonfinancial performance. Efforts to maintain and increase market share in targeted customer segments are usually preceded by retaining existing customers on customer segments. According to Gitman (2006), leverage is the use of assets or funds that have fixed costs to magnify returns (return) to the owner of the company. The company is a shipping company based on the order that the use of assets fluctuate in accordance with the company obtained orders. Operating leverage is no significant effect on nonfinancial performance of shipping companies in Indonesia. The company is a shipping company based on job order so that changes in lower sales as well as changes in operating income was also lower EBIT resulting Influence of operating leverage on non-financial performance is not significant.

This means that the high and low levels of operating leverage does not affect the performance of the non-financial enterprise Indonesian shipping. Increasing sales of ships is the purpose of the company in maintaining the company to continue to operate and manage all the assets of the company. Therefore, it can be concluded sales growth significantly influence the performance of the nonfinancial enterprise Indonesian shipping. Sales growth reflects the successful manifestation of the investment period of the past and can be used as a prediction of future growth.

\section{RECOMMENDATIONS}

For information:

Shipping

companies can grow and expand. It is able to increase profitability by increasing the shipping company's own capital and reducing a portion of the shipping company, so it will be more active equity and profitability will also be good. On the other hand if it continues to rely on capital from outside only, it will cause emergence of interest expense to be borne by the shipping company. Non-financial performance can be improved by providing fast service, good, and satisfactory to the consumer.

For Company: a) Based on data known to the shipping company's current debt level is greater than current assets, so that the working capital can support the operations of the company, then the current debt be reduced by seeking funds from the government or to obtain working capital from the progress of completion of the work. b) Providers of working capital on the shipping company should be available and not rely working capital funded by bank loans or borrowing from investors which is very volatile so that the shipping company is difficult to increase profits. The government should provide funding for working capital or to obtain working capital from the progress of completion of the work in order to obtain 
an increase in profits. The use of working capital in order to be optimized, that is not excessive or need, for any amount of funds greater than the amount needed to raise corporate property without being followed by a proportional increase in earnings, thus lowering the rate of return on investment. While any amount of funds lower provider payment means the company fails to afford the debt on time. Maintaining working capital used or scaled back is to increase sales so as to give a good effect on corporate earnings. c) Revalued on the structure of assets owned by the company which is not at high risk for the company in dealing with the problem of depreciation of property. d) Planning and Estimation of the cost of each to get the job must be calculated accurately and precisely so that the shipping company is not having trouble funding the project and did not experience a loss and delay in completion of the work.

\section{REFERENCES}

Baridwan, Zaki, 2005, Intermediate Accounting, BPFE, Yogyakarta

Brigham, E.F, and Louis C. Gapenski. 1996. Financial Management Theory and Practice. Sixth Edition. The Dryden Press International Edition. USA.

Brigham, Eugene F., and Phillips R. Daves, Intermediate Financial Management, 2004., Eighth Edition, South Western, United States.

Fahmi, Irham. 2011. Analysis of Financial Performance. New York: The alphabet.

Gitman, Lawrence J., 2003. Principles of Managerial Finance, Tenth Edition, Pearson Education, Inc., United States.

Husnan, Suad. 1993. Financial Management Theory and Applied. First Edition. Third mold. BPFE. Yogyakarta.

Jensen MC., And WH Meckling., 1976. Theory of the Firm: Managerial
Behavior, Agency Cost and Ownership Structure. Journal of Financial Economics (October), 193228.

Kaplan, Robert S, and David P. Norton, 1996. The Balanced Scorecard: Implementing Strategy Action Being. Translation: Peter R. Yosli Pasla. Erland. Jakarta.

Kieso, Donald E. Jerry J. Werygandt, and Terry D. Warfield. 2002. Intermediate Accounting IFRS Approach. 1st Edition Volume 1 and Volume 2 Set Intercorporated JohnWiley \& Sons: New York.

Kusuma, Hadri. 2005. Company Size and Profitability: An Empirical Study of Manufacturing Companies Listed on the Jakarta Stock Exchange. Journal of Economic Development: Islamic University of Indonesia. http://journal.uii.ac.id/index.php/JEP /article/viewFile/607/533.

Napa, Awat J. and Mulyadi. 1996. Corporate Financial Decision Theory and Empirical Testing Results. Second edition. Liberty. Yogyakarta. Nugroho, Aditya. ISO 9001, 2008. Work in Process, 5th Edition, AIMS Prime, Jakarta.

Nugroho, Setyo Budi. 2011. Effect Analysis Efficiency Working Capital, Liquidity And Solvency To Profitability (A Case Study at PT. Telekomunikasi Indonesia, Tbk). Journal of Business Administration. Semarang.

Nurak, Moa. 2001. Effect of Working Capital Policy Against ROA on Company Property / Real Estate Sign in Indonesian Capital Market. Thesis Graduate Program, University of Airlangga. Unpublished. Surabaya.

Penman, S.H. 2003. Financial Statement Analysis and Security Valuation. Second Editon: McGraw Hill.

Government Regulation No. 5 In 2010, the United Indonesia Cabinet within the framework of the National Medium 
Term Development Plan (RPJMN) 2010-2014.

Putra, Indo Ratmana. 2013. Analysis of Effect of Operating Leverage and Financial Leverage to Earning Per Share (Eps) Property Company Listed On The Stock Exchange (2007 to 2011). Journal of Management Studies, Volume 1 Number 1 January: 318-328.

Sen, Mehmet, Eda Oruç. 2009. Relationship between Efficiency Level of Working Capital Management and Return on Total Assets in Ise.http: //www.ccsenet.org/journal/index.php /ijbm/article/viewFile/2544/3495.

Shamsuddin, Lukman. 2000. Corporate Financial Management (Concept Application in: Planning, Monitoring, and Decision Making). PT. Grafindo Persada, Jakarta.

Titman, Sheri and Roberto Wessels. 1988. Determinant of Capital Structure. Journal of Finance. Volume XLIII. No. 1.

Weston, J. Fred and Thomas E. Copeland. 1997. Financial Management. Eighth Edition. Volume Two. Binarupa script. Jakarta.

Weston, J. Fred and Thomas E Coopeland. 1999. Financial Management, Wasana and Kibrandoko Jaka translation, Ninth Edition, Erland, Jakarta. 